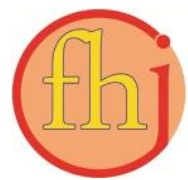

Faletehan Health Journal, 8 (2) (2021) 122-129

www. journal.Ippm-stikesfa.ac.id/ojs/index.php/FHJ

ISSN 2088-673X | e-ISSN 2597-8667

\title{
Peran Orang Tua dan Peran Teman Sebaya pada Perilaku Seksual Remaja
}

\author{
Adelse Prima Mulya ${ }^{1 *}$, Mamat Lukman ${ }^{1}$, Desy Indra Yani ${ }^{1}$ \\ ${ }^{1}$ Community Health Nursing Department, Universitas Padjadjaran \\ *Corresponding Author: adelse@unpad.ac.id
}

\begin{abstract}
Abstrak
Perilaku seksual remaja semakin sering dijumpai dalam kehidupan sehari-hari. Perilaku ini dapat dipengaruhi oleh kurangnya peran orang tua dalam mengawasi remaja serta pengaruh teman sebaya. Tujuan penelitian ini adalah untuk melihat bagaimana hubungan peran orang tua dan teman sebaya terhadap perilaku seksual remaja. Penelitian ini bersifat kuantitatif dengan desain cross sectional study. Populasi dalam penelitian adalah semua siswa kelas X dan XI yang ada di salah satu SMA Kota Bandung yang berjumlah 580 orang. Sampel diambil menggunakan rumus estimasi absolute precision dan didapatkan jumlah sampel sebanyak 246 orang siswa. Data dikumpulkan menggunakan kuesioner perilaku seksual remaja, peran orang tua dan peran teman sebaya. Keseluruhan kuesioner telah dilakukan uji Reabilitas dan uji Validitas. Data dianalisis menggunakan chi Square. Hasil penelitian ini menunjukkan bahwa $49,6 \%$ siswa berperilaku seksual berisiko tinggi, 53,3\% memiliki orang tua yang berperan tidak baik pada perilaku seksual remaja, $55,7 \%$ memiliki teman sebaya yang berperan besar dalam perilaku seksual mereka. Ada hubungan yang bermakna antara peran orang tua dengan perilaku seksual remaja, akan tetapi tidak ada hubungan yang bermakna antara peran teman sebaya dengan perilaku seksual remaja. Sekolah disarankan dapat membentuk peer group dan pendekatan milenial untuk merubah perilaku remaja.
\end{abstract}

Kata Kunci: Orang Tua, Perilaku Seksual, Remaja, Teman Sebaya

\section{Role of Parents and Peers in Adolescent Sexual Behaviour}

\begin{abstract}
Adolescent sexual behavior is increasingly found in everyday life. This behavior can be influenced by peers and the lack of parental role in supervising adolescents. The purpose of this study was to examine the relationship between the role of parents and peers in adolescent sexual behavior. This research was quantitative with a cross sectional study design. The study population was all tenth and eleventh graders of a senior high school in Bandung City, totaling 580 students. The samples were taken by using absolute precision estimation formula, and the sample size was 246 students. The data were collected by using a questionnaire of adolescent sexual behavior, parents role and peers role. All questionnaires had been tested for the reliability and validity. The data were analyzed by using chi Square. The results of this study showed that $49.6 \%$ of students had a high-risk sexual behavior, $53.3 \%$ had parents who played a bad role in adolescent sexual behavior, $55.7 \%$ had peers playing a major role in their sexual behavior. There was a significant relationship between the role of parents and adolescent sexual behavior; nevertheles, there was no significant relationship between the role of peers and adolescent sexual behavior. Schools were suggested to form peer groups and use millennial approaches to change adolescent behavior.

Keywords: Parents, Sexual Behavior, Adolescent, Peers
\end{abstract}


Faletehan Health Journal, 8 (2) (2021) 122-129

\section{Pendahuluan}

Perilaku seksual remaja semakin sering dijumpai dalam kehidupan sehari-hari. Prevalensi di Amerika menunjukkan hampir separo $(46,8 \%)$ dari siswa telah pernah melakukan aktivitas seksual (intercourse), dari jumlah tersebut hanya 59,1\% yang menggunakan kondom (Kann et al., 2012). Begitupun di Asia Tenggara, di wilayah Thailand perilaku seksual yang tidak aman menunjukkan angka yang cukup tinggi (Sirirassamee \& Sirirassamee, 2015). Data dari Infodatin Kemenkes RI menerangkan secara umum, remaja laki-laki di Indonesia lebih banyak menyatakan pernah melakukan seks pra nikah (intercose) dibandingkan perempuan (Kementerian Kesehatan Republik Indonesia, 2015). Dari survei yang sama didapatkan alasan hubungan seksual pra nikah karena rasa ingin tahu (57,5\% pria), terjadi begitu saja (38\% perempuan) dan dipaksa pasangan (12,6\% perempuan). Data dari BKKBN tahun 2014 mengenai survei di kota-kota besar terhadap keperawanan pada perempuan lajang dan didapatkan hasil bahwa 50\% tidak perawan di Jabodetabek, 54\% di Surabaya, 47\% di Bandung dan 52\% di Medan (BKKBN, 2018).

Perilaku seksual remaja apabila tidak dicegah akan berdampak bagi kesehatan dan masa depan remaja sendiri. Pengalaman berpacaran pada remaja akan mengganggu hubungan mereka secara psikologis ketika adanya paksaan terhadap pasangan untuk melakukan perilaku seksual (Collibee \& Furman, 2014). Penelitian yang dilakukan oleh Eaton et al., (2010) secara substansial perilaku seksual remaja yang masih aktif $34,2 \%$ saat ini akan semakin meningkatkan angka infeksi menular seksual (IMS), termasuk kehamilan usia muda yang tidak diinginkan. Penelitian lain menunjukkan, perilaku seksual remaja dapat mengakibatkan menurunnya keproduktifan remaja di masa yang akan datang, bisa karena diakibatkan oleh kehamilan yang tidak direncanakan, penularan virus HIV, serta masalahmasalah sosial lainya seperti kemiskinan dan kriminalitas (Kann et al., 2018). Penelitian lain yang dilakukan oleh Houck, Nugent, Lescano, Peters, \& Brown (2010) menjelaskan bukan hanya masalah kesehatan fisik dan sosial yang dapat ditimbulkan dari perilaku seksual pada remaja sekitar 23\% juga berdampak pada masalah psikologis (kejiwaan) remaja yang aktivitas seksualnya mengalami kekerasan dan penyimpangan seksual. Selain itu, dampak psikosial juga dapat ditimbulkan dari perilaku seksual remaja (Ybarra \& Mitchell, 2014). Penelitian yang dilakukan oleh Fish \& Pasley (2015) perilaku seksual remaja memiliki keunikan dan berbagai ragam akrivitas seksual; ada heteroseksual, heterofleksibel, biseksual dan LGB. Keunikan aktivitas seksual ini dapat beresiko gejala depresi, pikiran dan perilaku bunuh diri.

Adapun faktor-faktor yang mempengaruhi terjadi perilaku seksual remaja diantaranya adalah genetik, temen sebaya, gender dan budaya. Studi yang dilakukan oleh Bowleg et al (2015) faktor yang memungkinkan mempengaruhi perilaku seksual beresiko pada remaja yaitu adanya pengaruh dari gender dan budaya-spesifik tertentu. Pengaruh genetik pada perilaku seksual remaja melalui berbagai mekanisme langsung dan tidak langsung, termasuk perkembangan pubertas, kadar testosteron, dan sistem dopaminergik. Perbedaan genetik dapat secara sistematis dikaitkan dengan paparan ke lingkungan yang umumnya diperlakukan sebagai penyebab perilaku seksual (korelasi gen-lingkungan) (Harden, 2014). Kemudian penelitian oleh Wang et al., (2015) mengenai timbal balik antara peran orang tua, teman sebaya dan perilaku seksual remaja menunjukkan keterlibatan dan pengaruh teman sebaya untuk menimbulkan perilaku seksual beresiko sangat tinggi baik bagi remaja perepuan ataupun laki-laki, namun dalam dimensi lain, dengan adanya pengawasan dan pemantuan yang tinggi pada anak hasil dapat menurunkan perilaku seksual beresiko pada remaja. Penelitian yang dilakukan oleh Kreager, Staff, Gauthier, Lefkowitz, \& Feinberg (2016) menyebutkan remaja wanita yang mengatakan bahwasanya pernah melakukan perilaku seksual akan mengalami penurunan pertemanan teman sebayanya, sebaliknya remaja laki-laki yang menyampaikan bahwa pernah melakukan perilaku seksual akan mengalami peningkatan dalam penerimaan teman sebaya. Penelitian ini juga membahas bahwa perlu mengubah persepsi remaja yang keliru dalam lingkungan sosial dan tradisional, bahwa perilaku seksual baik ringan ataupun berat bukanlah patokan dalam penerimaan dalam sebuah pertemanan.

Melihat kondisi perilaku seksual ini cukup merugikan baik bagi masa depan remaja, keluarga maupun sekolah, hal ini perlu diketahui terlebih 
dahulu perilaku penyimpangan seksual seperti apa yang telah dilakukan oleh remaja pada saat ini agar tidak berkembang lebih lanjut kedepannya. Intervensi yang diberikan berupa pendidikan dan promosi kesehatan bertujuan untuk meningkatkan pengetahuan remaja dan keluarga mengenai perilaku seksual tersebut dapat dilakukan setelah mengetahui penyebab perilaku seksual pada remaja. Dari survey awal yang telah dilakukan kepada beberapa orang siswa di salah satu SMA di kota Bandung, menemukan bahwa mereka umumnya risih membicarakan hal-hal yang menyangkut masalah seksualitas dengan orang tua dikarenakan orang tua seakan-akan membuat jarak dengan mereka tentang masalah itu. Mereka lebih senang mendiskusikan hal tersebut dengan temanteman mereka, dan 3 orang diantaranya pernah berpegangan tangan dengan pacar, 2 orang pernah menonton video porno bersama temannya.

Bertitik tolak dari keterangan-keterangan diatas, terdapat kemungkinan yang sangat besar meningkatnya kejadian perilaku seksual berisiko pada remaja. Lemahnya pengawasan orang tua, serta keterbukaan informasi global membuat remaja bersama seusianya kadang salah mengartikan dan kadang salah dalam berperilaku. Oleh karena itu, penelitian ini bertujuan untuk melihat hubungan peran orang tua dan peran teman sebaya dengan perilaku seksual beresiko remaja di salah satu SMA di Kota Bandung.

\section{Metodologi Penelitian}

Penelitian ini merupakan penelitian kuantitatif deskriptif analitik untuk mengetahui hubungan peran orang tua dan peran teman sebaya dengan perilaku seksual remaja di salah satu SMA di Kota Bandung. Desain Penelitian yang digunakan adalah Cross Sectional dimana peran orang tua, dan teman sebaya merupakan variabel bebas sedangkan perilaku seksual sebagai variabel terikat diteliti pada waktu yang sama. Populasi penelitian adalah siswa kelas X dan XI yang berjumlah 580 orang. Sampel dihitung menggunakan rumus estismasi absolute presisi didapatkan jumlah sampel sebanyak 246 siswa. Siswa kelas XII tidak dilibatkan dalam penelitian ini dikarenakan tidak diizinkan dari pihak sekolah karena harus mengikuti kegiatan tambahan untuk persiapan kelulusan. Adapun kriteria inklusi sampel antara lain: 1) siswa harus terdaftar sebagai siswa yang aktif di SMA tersebut, 2) mau mengikuti kegiatan penelitian dari awal sampai akhir, 3) kelas $\mathrm{X}$ dan XI.

Data diambil menggunakan tiga kuesioner diantaranya; kuesioner perilaku seksual remaja, peran orang tua dan peran teman sebaya. Keseluruhan kuesioner telah dilakukan uji Validitas dan uji Reabilitas dengan nilai Alpha Cronbach's $(0.9),(0,8)$ dan $(0.8)$. Data dianalisis menggunakan univariat dan bivariat. Untuk analisis univariat, selain data demografi siswa pada variable perilaku seksual remaja akan dibagi menjadi perilaku seksual berisiko tinggi dan rendah. Peran orang tua akan dibagi menjadi berperan baik dan buruk. Peran teman sebaya dibagi menjadi berperan baik dan buruk. Analisis bivariat yang digunakan untuk mengetahui hubungan peran orang tua dan peran teman sebaya terhadap perilaku seksual remaja adalah analisis Chi-square. Penelitian ini sudah mendapatkan persetujuan etik di Komisi Etik Penelitian Unpad dengan nomor surat 175/UN6.KEP/EC/2020.

\section{Hasil dan Pembahasan}

Dengan jumlah Sampel 246 siswa remaja SMA yang terdiri dari 140 siswa laki-laki dan 106 siswa perempuan. Berdasarkan karakteristik demografi siswa didapatkan sebagai berikut:

Tabel 1: Data Demografi Remaja di SMA Kota Bandung ( $\mathrm{N}=246)$

\begin{tabular}{lcc}
\hline \multicolumn{1}{c}{ Variabel } & f & \% \\
\hline Usia & & \\
15 Tahun & 10 & 4,1 \\
16 Tahun & 93 & 37,8 \\
17 Tahun & 18 & 56,1 \\
18 Tahun & 5 & 2 \\
\hline Jenis Kelamin & & \\
$\quad$ Laki-laki & 140 & 56,9 \\
$\quad$ Perempuan & 106 & 43,1 \\
\hline Usia Haid Pertama Kali & & \\
(Perempuan) & & \\
$\quad$ 10 Tahun & 22 & 20,8 \\
11 Tahun & 20 & 18,9 \\
12 Tahun & 30 & 28,3 \\
13 Tahun & 17 & 16 \\
$\geq 14$ Tahun & 17 & 16 \\
\hline Usia Mimpi Basah & & \\
Pertama Kali (Laki-Laki) & & \\
$\quad \leq 11$ Tahun & 42 & 17,1 \\
12 Tahun & 42 & 17,1 \\
13 Tahun & 58 & 23,5
\end{tabular}


Faletehan Health Journal, 8 (2) (2021) 122-129

\begin{tabular}{lcc}
\hline \multicolumn{1}{c}{ Variabel } & f & \% \\
\hline 14 Tahun & 62 & 25,2 \\
$\geq 15$ Tahun & 42 & 17,1 \\
\hline
\end{tabular}

Dari tabel 1. diatas dapat diketahui bahwa dari 246 siswa yang paling banyak berusia 17 tahun $56,1 \%$, berjenis kelamin laki-laki $56,9 \%$, usia haid pertama bagi perempuan paling domian di usia 12 tahun $28,3 \%$, dan mimpi basah pertama bagi lakilaki paling banyak di usia 14 tahun 25,2\% .

Perilaku seksual remaja, peran orang tua, dan peran teman sebaya SMA Kota Bandung dapat dilihat secara keseluruhan sebagai berikut:

Tabel 2: Perilaku Seksual Remaja, Peran Orang Tua, Peran Teman Sebaya di SMA Kota Bandung $(\mathrm{N}=246)$

\begin{tabular}{lcc}
\hline \multicolumn{1}{c}{ Variabel } & f & \% \\
\hline Perilaku Seksual Remaja & & \\
$\quad$ Berisiko Tinggi & 122 & 49,6 \\
Berisiko Rendah & 124 & 50,4 \\
\hline Peran Orang Tua & & \\
$\quad$ Berperan Tidak Baik & 131 & 53,3 \\
$\quad$ Berperan Baik & 115 & 46,7 \\
\hline Peran Teman Sebaya & & \\
$\quad$ Berperan Besar & 137 & 55,7 \\
Berperan Kecil & 109 & 44,3 \\
\hline
\end{tabular}

Berdasarkan tabel 2 diatas dapat diketahui bahwa hampir separuh $(49,6 \%)$ remaja melakukan perilaku seksual berisiko tinggi, lebih dari separuh remaja $(53,3 \%)$ memiliki orang tua yang berperan tidak baik terhadap perilaku seksual, lebih dari separuh remaja $(55,7 \%)$ memiliki pengaruh teman yang besar terhadap perilaku seksual.

Berdasarkan tabel 3 dapat dilihat bahwa dari 131 remaja yang memiliki peran orang tua tidak baik terdapat 80 orang $(61,1 \%)$ berperilaku seksual berisiko tinggi. Sedangkan peran orang tua yang baik dari 115 remaja terdapat 42 orang $(36,5 \%)$ responden berperilaku seksual beresiko tinggi. Berdasarkan uji statistik didapatkan nilai $p<0,05$ $(0,000)$ ini menunjukkan adanya hubungan yang bermakna antara peran orang tua dengan perilaku seksual remaja SMA di Kota Bandung.

Berdasarkan tabel 4 dapat dilihat bahwa dari 137 remaja yang memiliki pengaruh teman sebaya besar didapatkan 65 orang $(47,4 \%)$ berperilaku seksual berisiko tinggi. Sedangkan peran teman sebaya yang berpengaruh kecil sebanyak 109 remaja terdapat 57 orang $(52,3 \%)$ yang berperilaku seksual beresiko tinggi. Berdasarkan uji statistik didapatkan nilai $p>0,05(0,531)$ ini menunjukkan tidak adanya hubungan yang bermakna antara peran teman sebaya.

\section{Hubungan Peran Orang Tua dengan Perilaku Seksual Remaja}

Hasil penelitian menunujukkan terdapat hubungan antara peran orang tua dengan perilaku seksual remaja SMA di Kota Bandung. Pada penelitian ini didapatkan $(40,7 \%)$ orang tua dari responden tidak pernah memberikan informasi tentang masalah datangnya haid pertama (pada anak perempuan) atau mimpi basah pada anak lakilaki, $(41,9 \%)$ tidak pernah membicarakan masalah perubahan yang terjadi pada organ seksual dimasa akil baligh atau pubertas, $(41,9 \%)$ tidak pernah membicarakan masalah hubungan seksual sebelum menikah dan akibatnya, (43,1\%) tidak pernah membicarakan masalah akibat hamil yang terjadi pada usia muda.

Hal senada juga disampaikan Kincaid, Jones, Sterrett, \& McKee (2012) untuk membentuk perilaku yang baik terhadap anak, terutama menghindari perilaku sekusual pada remaja sangat dibutuhkan peran serta orang tua yang sangat kuat terutama dari sisi kedekatan emosional dan kehangatan dalam bersikap terhadap anak. Kemudian dalam memberikan perhatian ataupun informasi mengenai perilaku yang berhubungan dengan seksual diharapkan harus sesuai gender, maksudnya seorang Ayah dengan anak lakilakinya dan seorang ibu dengan anak perempuannya. Hasil penelitian ini menunjukkan peran gender adalah salah satu faktor yang sangat perperan penting dalam pengenbangan perilaku seksual remaja.

Penelitian yang dilakukan Simons, Sutton, Simons, Gibbons, \& Murry (2016) remaja akan sangat memiliki resiko terhadap perilaku seksual terutama pada wanita 55\% $(\mathrm{N}=629)$ jika orang tua tidak memiliki kriteria yang bagus dalam memberikan bimbingan atau perhatian terhadap anak. Adapun kategori bimbingan yang tidak bagus dimiliki oleh orang tua diantaranya dukungan orang tua yang kurang terhadap anak, orang tua yang berperilaku kekerasan terhadap anak serta manajemen yang kurang baik terhadap anak.

Selanjutnya, penelitian yang dilakukan oleh Kerpelman, McElwain, Pittman, \& Adler-Baeder (2016) menjelaskan bahwa perilaku seksual beresiko pada remaja dapat diakitkan dengan ada atau tidak nya control secara psikologis oleh orang 
tua kemudian kurangnya dukungan terhadap kepercayaan diri anak, serta rendahnya pengawasan terhadap identitas pasangan anak. Kemudian penelitia ini juga menjelaskan hasil dapat berbeda jika dukungan yang diberikan itu berasal dari orang tua kandung dan oran tua tiri. Wang, Stanton, Deveaux, Li, \& Lunn (2015) menunjukkan dalam penelitiannya bahwa peran orang tua cukup besar dalam mencegah perilaku seksual beresiko pada remaja yaitunya dengan adanya pengawasan yang cukup terhadap anak reamaja. Dalam penelitian ini juga menjelaskan peran teman sebaya lebih mendominasi terhadap kejadian perilaku seksual beresiko pada remaja dibandingkan dengan rendahnya pengawasan orang tua terhadap anak. Pola asuh orang tua terhadap remaja juga sangat menetukan output perilaku remaja tersebut, kehangatan dan kedekatan emosional antara orang tua dan anak ataupun kekerasan. Dalam penelitian ini menunjukkan dari 1.482 remaja yang ditindaklanjuti selama 9 tahun (rentang usia $=$ $12,74)$, remaja dengan pola asuh yang kurang tepat yaitunya perilaku kekerasan orang tua dapat menimbulkan berbagai perilaku menyimpang yang dilakukan oleh remaja diantaranya kenakalan remaja, penurunan pencapaian di akademik, kemudian diikuti dengan perilaku seksual awal (Hentges \& Wang, 2018).

Bila dilihat dari segi hubungan responden dengan orang tua, dapat disimpulkan bahwa semakin buruk hubungan responden dengan orang tua maka semakin tinggi persentase terjadinya perilaku seksual beresiko karena tidak adanya komunikasi yang terbuka antara orang tua dan remaja sehingga tidak ada lagi rasa saling percaya dan menghargai anak terhadap orang tuanya. Begitupun sebaliknya, bila semakin baik peran orang tua maka maka semakin sedikit terjadinya perilaku seksual beresiko tinggi ini dikarenakan terjalinnya hubungan baik antara orang tua dan anak dan terciptanya rasa saling percaya dan menghargai antara orang tua dan anak.

Secara hakekat keluarga memiliki 8 fungsi yang harus diperankan dalam membentuk kepribadian remaja yakni fungsi keagamaan yang dapat diwujudkan dalam bentuk keimanan, ketaqwaan dan aplikasinya dalam kehidupan masyarakat,fungsi sosial budaya yang dapat dicerminkan dari sikap saling menghargai,patuh pada kaedah dan norma yang berlaku pada masyarakat, fungsi cinta kasih tercermin dalam kehidupan yang harmonis dan rukun, fungsi melindungi yang menumbuhkan rasa aman dan kehangatan yang tida batas bandingan baik lahir maupun batin, fungsi reproduksi yang merupakan mekanisme keturunan untuk melanjutkan keturunan yang direncanakan untuk kesejahteraan, fungsi sosial pendidikan yang dapat meningkatkan kualitas pendidikan keluarga, fungsi ekonomi dapat diwujudkan dalam bentuk mata pencaharian dan hidup berkecukupan dan fungsi pembinaan lingkungan yang diwujudkan keluarga yang mampu menempatkan diri secara serasi selaras dan seimbang ("Renstra Perwakilan BKKBN Provinsi Jawa Barat Tahun 2020-2024 - BKKBN | Jawa Barat," n.d.).

Tabel 3: Hubungan Peran Orang Tua dengan Perilaku Seksual Remaja di SMA Kota Bandung (N=246)

\begin{tabular}{|c|c|c|c|c|c|c|c|}
\hline \multirow{3}{*}{ Peran Orang Tua } & \multicolumn{4}{|c|}{ Perilaku Seksual } & \multirow{2}{*}{\multicolumn{2}{|c|}{ Total }} & \multirow{3}{*}{$P$ Value } \\
\hline & \multicolumn{2}{|c|}{ Berisiko Tinggi } & \multicolumn{2}{|c|}{ Berisiko Rendah } & & & \\
\hline & $\mathbf{F}$ & $\%$ & $\mathbf{F}$ & $\%$ & $\mathbf{F}$ & $\%$ & \\
\hline Tidak Baik & 80 & 61,1 & 51 & 38,9 & 131 & 100 & \multirow{3}{*}{0,00} \\
\hline Baik & 42 & 36,5 & 73 & 63,5 & 115 & 100 & \\
\hline Jumlah & 122 & 49,6 & 124 & 50,4 & 123 & 100 & \\
\hline
\end{tabular}

Tabel 4: Hubungan Peran Teman Sebaya dengan Perilaku Seksual Remaja di SMA Kota Bandung (N=246)

\begin{tabular}{|c|c|c|c|c|c|c|c|}
\hline \multirow{3}{*}{$\begin{array}{c}\text { Pengaruh Teman } \\
\text { Sebaya }\end{array}$} & \multicolumn{4}{|c|}{ Perilaku Seksual } & \multirow{2}{*}{\multicolumn{2}{|c|}{ Total }} & \multirow{3}{*}{$P$ Value } \\
\hline & \multicolumn{2}{|c|}{ Berisiko Tinggi } & \multicolumn{2}{|c|}{ Berisiko Rendah } & & & \\
\hline & $\mathbf{F}$ & $\%$ & $\mathbf{F}$ & $\%$ & $\mathbf{F}$ & $\%$ & \\
\hline Berpengaruh Besar & 65 & 47,4 & 72 & 52,4 & 137 & 100 & \multirow{3}{*}{0,53} \\
\hline Berpengaruh Kecil & 57 & 52,3 & 52 & 47,7 & 109 & 100 & \\
\hline Jumlah & 122 & 49,6 & 124 & 50,4 & 123 & 100 & \\
\hline
\end{tabular}


Faletehan Health Journal, 8 (2) (2021) 122-129

\section{Hubungan Peran Teman Sebaya dengan Perilaku Seksual Remaja}

Hasil penelitian menunjukkan tidak adanya hubungan yang bermakna antara peran teman sebaya dengan perilaku seksual remaja. Pada penelitian ini didapatkan $(20,7 \%)$ ikut berpacaran karena ajakan teman, $(64,6 \%)$ pernah melihat situs porno karena ajakan teman, (63\%) pernah menonnton video porno beramai-ramai dengan teman, $(6,9 \%)$ teman pernah membujuk untuk melakukan hubungan seksual dengan lawan jenis. Hal ini disebabkan karena apabila seseprang remaja melakukan perilaku seksual yang beresiko tinggi tidak hanya disebabkan oleh pengaruh teman sebaya saja, hali ini bisa disebabkan oleh tidak harmonisnya hubungan dengan orang tua dan media yang pada saat ini yang sudah canggih yang dapat mengakses apapun. Perilaku seksual yang beresiko ini juga tergantung dari iman remaja itu sendiri dan bagaimana keyakinannya terhadap Tuhan sehingga ia dapat terhindar dari perilaku yang negatif.

Penelitian yang dilakukan oleh Kreager, Staff, Gauthier, Lefkowitz, \& Feinberg (2016) menyebutkan remaja wanita yang mengatakan pernah melakukan perilaku seksual akan mengalami penurunan pertemanan teman sebayanya, sebaliknya remaja laki-laki yang menyampaikan bahwa pernah melakukan perilaku seksual akan mengalami peningkatan dalam penerimaan teman sebaya. Penelitian ini juga membahas bahwa perlu mengubah persepsi remaja yang keliru dalam lingkungan social dan tradisional, bahwa perilaku seksual baik ringan ataupun berat bukanlah patokan dalam penerimaan dalam sebuah pertemanan. Hal yang serupa juga ditemukan dalam penelitian Baumgartner, Sumter, Peter, \& Valkenburg (2015). Teman sebaya memiliki efek yang kuat pada kepercayaan, sikap dan perilaku sesama remaja. Hasil dari penelitian ini menunujukkan kecenderungan aktivitas seksual dan hubungan romantic antar pasangan remaja akan cepat menyebar ke remaja lain, namun tidak pada ketertarikan sesame jenis tidak menyebar ke remaja lain.

Wang et al., (2015) dalam penelitiannya mengenai timbal balik antara peran orang tua, teman sebaya dan perilaku seksual remaja. Hasil studinya menunjukkan keterlibatan dan pengaruh teman sebaya untuk menimbulkan perilaku seksual beresiko sangat tinggi baik bagi remaja perepua ataupun laki-laki, namun dalam dimensi lain, dengan adanya pengawasan dan pemantuan yang tinggi pada anak hasil dapat menurunkan perilaku seksual beresiko pada remaja. Untuk remaja lakilaki perilaku sesksual berisiko lebih besar dikarenakan pemantauan orang tua rendah, untuk remaja perempuan, perilaku seksual beresiko meningkat dikarenakan keterlibatan teman sebaya yang cenderung tinggi. Penelitian lain menyebutkan, remaja mengalami transformasi perkembangan kritis yang meningkatkan arti penting pengaruh teman sebaya. Interaksi teman sebaya (perilaku romantis dengan pasangan remaja) memiliki pengaruh positif dan negatif pada sikap dan perilaku remaja yang terkait dengan hubungan romantis dan perilaku seksual. Bahwa teman sebaya mempengaruhi hubungan mereka dan perilaku seksual termasuk menekan teman kedalam sebuah hubungan, membangun hubungan, persepsi popularitas dan status social serta menciptakan norma dan harapan hubungan. Teman sebaya yang cenderung berperilaku romantis juga memotivasi hubungan dan perilaku seksual kepada remaja yang lain dengan alas an tidak menyakiti hanya saja ingin menyenangkan pasangan remaja (Suleiman \& Deardorff, 2015).

Penelitian senada yang dilakukan oleh Sneed, Tan, \& Meyer (2015) dari 212 remaja yang ditetiliti ditemukan bahwa komunikasi orang tua terhadap remaja dan peran teman sebaya sangat penting dalam pembentukan perilaku remaja. Penelitian ini menjelaskan sikap orang tua dan teman sebaya akan membentuk kepercayaan diri remaja dalam membatasi perilaku seksual serta niat untuk melakukan hubungan seksual pada masa remaja. Selain dorongan dan motivasi dari teman sebaya pada masa remaja, perilaku seksual dapat terjadi akibat dari pelecehan seksual yang dilakukan oleh remaja seusianya. Seperti yang dijelaskan dalam penelitian yang dilakukan oleh Martin-Storey \& Crosnoe (2014), studi ini dilakukan kepada remaja berusisa 15 tahun $(\mathrm{N}=957)$ pada remaja laki-laki dan perempuan. Untuk anak perempua, pelecehan remaja merupakan media yang sangat kuat untuk terjadinya perilaku seksual pada remaja, sehingga kemungkinan besar remaja perempuan akan "terpaksa" melakukan perilaku seksual dengan tindakan ini. Untuk anak laki-laki cenderung kasus pelecehan yang meninbulkan perilaku seksual sangat minim. 
Kelompok teman sebaya merupakan interaksi bagi remaja pada lingkungan sosial. Mereka mulai belajar bergaul dan berinteraksi dengan orang lain yang bukan anggota keluarganya. Ini dilakukan agar mereka mendapat pengakuan dan penerimaan dari kelompok teman sebaya seehingga akan tercipta rasa aman. Hubungan siosial dengan teman sebaya sangat penting bagi perkembangan pribadi. Maka sebaiknya peran teman sebaya adalah menyediakan informasi dan perbandingan tentang dunia diluar keluarga. Remaja menerima umpan balik tentang kemampuan mereka dari kelompok teman sebaya kemudian mengevaluasi apakah yang mereka lakukan lebih baik, sama atau lebih jelek buruk dari yang dilakukuan anak-anak yang lain. Kelompok memenuhi kebutuhan pribadi remaja, menghargai mereka,menyediakan informasi, menaikkan harga diri, dan memberi mereka suatu identitas. Remaja bergabung pada suatu kelompok dikarenakan akan memiliki kesempatan untuk menerima penghargaan dan informasi yang penting.

Adapun kaitan teman sebaya dengan perilaku seksual adalah karena teman sebaya mempunyai andil yang besar dalam mempengaruhi perilaku remaja, karena remaja menanggap pada kelompok remaja adalah suatu identitas diri yang harus dipertahankan. Jika tidak diikuti maka remaja akan dikucilkan dari kelompoknya. Hal itu terkait dengan kurang kontrol pada diri remaja seperti kurangnya rasa percaya diri,kurang keterampilan berkomunikasi, sulit menolak ajakan teman, tidak tegas, kurangnya nilai keagamaan dan rendahnya kemampuan dalam menganbil keputusan. Menurut analisa peneliti pengaruh teman sebaya yang kurang baik dapat mengakibatkan perilaku seksual yang beresiko tinggi karena remaja cendrung untuk berkumpul dengan kelompoknya, rasa persamaan dan dan ingin meniru perilaku teman sekelompok sehingga pengaruh teman sebaya lebih kuat.

\section{Simpulan}

Hasil penelitian ini menunjukkan bahwa $(49,6 \%)$ melakukan perilaku seksual berisiko tinggi, $(53,3 \%)$ memiliki orang tua yang berperan tidak baik terhadap perilaku seksual, $(55,7 \%)$ teman sebayanya berpengaruh besar terhadap perilaku seksual, adanya hubungan yang bermakna antara peran orang tua dengan perilaku seksual remaja, tidak adanya hubungan yang bermakna antara peran teman sebaya dengan perilaku seksual remaja. Sekolah disarankan dapat membentuk peer group dan pendekatan milenial untuk merubah perilaku remaja.

\section{Referensi}

Baumgartner, S. E., Sumter, S. R., Peter, J., \& Valkenburg, P. M. (2015). Sexual selfpresentation on social network sites: Who does it and how is it perceived? Computers in Human Behavior. https://doi.org/10.1016/j.chb.2015.03.061

BKKBN. (2018). Survei demografi kesehatan Indonesia 2017: Kesehatan reproduksi remaja. Demographic and Health Survey (DHS).

Bowleg, L., Burkholder, G. J., Noar, S. M., Teti, M., Malebranche, D. J., \& Tschann, J. M. (2015). Sexual Scripts and Sexual Risk Behaviors Among Black Heterosexual Men: Development of the Sexual Scripts Scale. Archives of Sexual Behavior. https://doi.org/10.1007/s10508-013-0193-y

Collibee, C., \& Furman, W. (2014). Impact of sexual coercion on romantic experiences of adolescents and young adults. Archives of Sexual Behavior. https://doi.org/10.1007/s10508-013-0256-0

Eaton, D. K., Kann, L., Kinchen, S., Shanklin, S., Ross, J., Hawkins, J., ... Centers for Disease Control and Prevention (CDC). (2010). Youth risk behavior surveillance - United States, 2009. Morbidity and Mortality Weekly Report. Surveillance Summaries (Washington, D.C. : 2002).

Fish, J. N., \& Pasley, K. (2015). Sexual (Minority) Trajectories, Mental Health, and Alcohol Use: A Longitudinal Study of Youth as They Transition to Adulthood. Journal of Youth and Adolescence. https://doi.org/10.1007/s10964015-0280-6

Harden, K. P. (2014). Genetic influences on adolescent sexual behavior: Why genes matter for environmentally oriented researchers. Psychological Bulletin. https://doi.org/10.1037/a0033564

Hentges, R. F., \& Wang, M. Te. (2018). Gender Differences in the Developmental Cascade From Harsh Parenting to Educational Attainment: An Evolutionary Perspective. Child Development. https://doi.org/10.1111/cdev.12719

Houck, C. D., Nugent, N. R., Lescano, C. M., Peters, A., \& Brown, L. K. (2010). Sexual abuse and sexual risk behavior: Beyond the 
Faletehan Health Journal, 8 (2) (2021) 122-129

impact of psychiatric problems. Journal of Pediatric Psychology. https://doi.org/10.1093/jpepsy/jsp111

Kann, L., Kinchen, S., Shanklin, S. L., Flint, K. H., Kawkins, J., Harris, W. a, ... Zaza, S. (2012). Youth risk behavior surveillance--United States, 2013. Morbidity and Mortality Weekly Report. Surveillance Summaries (Washington, D.C. : 2002).

Kann, L., Whittle, L., Ethier, K. A., Lowry, R., Shanklin, S. L., Thornton, J., ... Chyen, D. (2018). Youth Risk Behavior Surveillance United States, 2017. MMWR. Surveillance Summaries. https://doi.org/10.15585/mmwr.ss6708a1

Kementerian Kesehatan Republik Indonesia. (2015). Situasi Kesehatan Reproduksi Remaja (p. 8). p. 8. Jakarta: Pusdiklat Kemenkes RI.

Kerpelman, J. L., McElwain, A. D., Pittman, J. F., \& Adler-Baeder, F. M. (2016). Engagement in Risky Sexual Behavior: Adolescents' Perceptions of Self and the Parent-Child Relationship Matter. Youth and Society. https://doi.org/10.1177/0044118X13479614

Kincaid, C., Jones, D. J., Sterrett, E., \& McKee, L. (2012). A review of parenting and adolescent sexual behavior: The moderating role of gender. Clinical Psychology Review. https://doi.org/10.1016/j.cpr.2012.01.002

Kreager, D. A., Staff, J., Gauthier, R., Lefkowitz, E. S., \& Feinberg, M. E. (2016). The Double Standard at Sexual Debut: Gender, Sexual Behavior and Adolescent Peer Acceptance. Sex Roles. https://doi.org/10.1007/s11199016-0618-x

Martin-Storey, A., \& Crosnoe, R. (2014). Peer Harassment and Risky behavior among sexual minority girls and boys. American Journal of Orthopsychiatry.

https://doi.org/10.1037/h0098854

Renstra Perwakilan BKKBN Provinsi Jawa Barat Tahun 2020-2024 - BKKBN | Jawa Barat. (n.d.). Retrieved April 13, 2021, from http://jabar.bkkbn.go.id/?wpdmpro=renstraperwakilan-bkkbn-provinsi-jawa-barat-tahun2020-2024

Simons, L. G., Sutton, T. E., Simons, R. L., Gibbons, F. X., \& Murry, V. M. B. (2016). Mechanisms That Link Parenting Practices to Adolescents' Risky Sexual Behavior: A Test of Six Competing Theories. Journal of Youth and Adolescence. https://doi.org/10.1007/s10964-015-0409-7

Sirirassamee, T., \& Sirirassamee, B. (2015). Health risk behavior among thai youth: National survey 2013. Asia-Pacific Journal of Public Health. https://doi.org/10.1177/1010539514548759

Sneed, C. D., Tan, H. P., \& Meyer, J. C. (2015). The Influence of Parental Communication and Perception of Peers on Adolescent Sexual Behavior. Journal of Health Communication. https://doi.org/10.1080/10810730.2015.1018 584

Suleiman, A. B., \& Deardorff, J. (2015). Multiple Dimensions of Peer Influence in Adolescent Romantic and Sexual Relationships: A Descriptive, Qualitative Perspective. Archives of Sexual Behavior. https://doi.org/10.1007/s10508-014-0394-z

Wang, B., Stanton, B., Deveaux, L., Li, X., \& Lunn, S. (2015). Dynamic relationships between parental monitoring, peer risk involvement and sexual risk behavior among Bahamian mid-adolescents. International Perspectives on Sexual and Reproductive Health. https://doi.org/10.1363/4108915

Ybarra, M. L., \& Mitchell, K. J. (2014). "sexting" and its relation to sexual activity and sexual risk behavior in a national survey of adolescents. Journal of Adolescent Health. https://doi.org/10.1016/j.jadohealth.2014.07. 012 